\title{
EFFECT OF Rhizobium INOCULATION OF SEEDS AND FOLIAR FERTILIZATION ON PRODUCTIVITY OF Pisum sativum L.
}

\author{
Tadeusz Zając, Agnieszka Klimek-Kopyra', Andrzej Oleksy \\ Institute of Crop Production, The Hugo Kołłątaj University of Agriculture in Kraków \\ A. Mickiewicza 21, 31-120 Krawków, Poland \\ e-mail: aklimek@ur.krakow.pl
}

Received: 04.03.2012

\begin{abstract}
Pea (Pisum sativum L.) is the second most important grain legume crop in the world which has a wide array of uses for human food and fodder. One of the major factors that determines the use of field pea is the yield potential of cultivars. Presently, pre-sowing inoculation of pea seeds and foliar application of microelement fertilizers are prospective solutions and may be reasonable agrotechnical options. This research was undertaken because of the potentially high productivity of the 'afila' morphotype in good wheat complex soils. The aim of the study was to determine the effect of vaccination with Rhizobium and foliar micronutrient fertilization on yield of the afila pea variety. The research was based on a two-year (2009-2010) controlled field experiment, conducted in four replicates and carried out on the experimental field of the Bayer company located in Modzurów, Silesian region. experimental field soil was Umbrisol - slightly degraded chernozem, formed from loess. Nitragina inoculant, as a source of symbiotic bacteria, was applied before sowing seeds. Green area index (GAI) of the canopy, photosynthetically active radiation (PAR), and normalized difference vegetation index (NDVI) were determined at characteristic growth stages. The presented results of this study on symbiotic nitrogen fixation by leguminous plants show that the combined application of Nitragina and Photrel was the best combination for productivity. Remote measurements of the pea canopy indexes indicated the formation of the optimum leaf area which effectively used photosynthetically active radiation. The use of Nitragina as a donor of effective Rhizobium for pea plants resulted in slightly higher GAI values and the optimization of PAR and NDVI. It is not recommended to use foliar fertilizers or Nitragina separately due to the slowing of pea productivity.
\end{abstract}

Key words: Pisum sativum L., inoculation, foliar fertilization, plant growth indices, traits, yield

\section{INTRODUCTION}

Pea and bean are traditionally edible leguminous plants in Europe (S m i 1, 1997). Currently, field pea is cultivated as an agricultural plant for food and fodder purposes, but seed and overground biomass yield are very changeable due to the quality of the habitat, the weather pattern during the growing season, and yield potential of cultivars ( $\mathrm{J}$ e u f f r o y and $\mathrm{Se}$ billote, 1997; B a ig orri et al. 1999; Carranca et al. 1999; Poggio et al. 2005; Annicchiarico and I a n n c c i , 2008; $\mathrm{Zaj}$ ą c et al. 2012). It is believed that leguminous plants, including field pea, are suitable for ecological agriculture in temperate climate (Corre-Hellou and Crozat, 2005). Recently, field pea may also become an important plant for sustainable agriculture because of its high yielding potential, which allows one to collect as much as 300 $\mathrm{kg} \mathrm{N} \mathrm{ha}{ }^{-1}$ from aboveground biomass, of which $70 \%$ is deposited in seeds (J e uffroy and Ney, 1997). $\mathrm{K}$ li me k and Z a jąc (2009) suggested that in spite of the impressive progress in pea productivity, which results from the synergistic effect of farming and agriculture, this plant is still unable to fulfill the needs of farmers. Therefore, a continuous reduction of pea acreage in favour of soybean (world) and rape (Europe) is observed.

The occurrence of soil drought during the growing season of pea strongly reduces the nitrogen fixation process (Carranca et al. 1999). Moreover, Armstrong et al. (1994) stated that nitrogen fixation of pea during the growing period in more humid and colder regions of Australia reached $100 \mathrm{~kg} \mathrm{~N} \times$ $\mathrm{ha}^{-1}$. It is emphasized that water and nitrogen availability during the growing period of pea determine 
the production capacity of its crop ( $\mathrm{J}$ e u f f r o y and $\mathrm{Ney}, 1997$ ). Jensen (1996) determined that pea uses only a small part of soil nitrogen - during one growing season it obtains only $22 \mathrm{~kg} \mathrm{~N} \times \mathrm{ha}^{-1}$ from soil. Corre-Hellou and Crozat (2005) showed that in 1999 and 2000 'Nitouche', a high-yielding pea variety, was able to fix 60.1 and $65.1 \%$ of total accumulated nitrogen, respectively. According to D u n et al. (2006), low soil nitrogen content inhibits the growth of pea plants and simultaneously stops the formation of lateral branches. On the other hand, too high concentration of mineral forms of nitrogen, originating from mineral fertilization, causes intensive elongation growth of the main and lateral shoots. This increases the growth of aboveground biomass, leads to early crop lodging and deteriorates the relationship between the generative and vegetative parts of plants. In agriculture, this results in the impossibility of economically effective pea cultivation for seed, because nitrogen fertilization extends the plant growing season and increases the susceptibility to canopy lodging (Jeuffroy and Sebillote 1997; Martyniak, 1997). B or o s and S a w i c ki (1997) emphasize that new high-yielding pea cultivars have high soil and cultivation technology requirements. It may be assumed with high probability that pre-sowing inoculation of pea seeds and foliar application of microelement fertilizers are currently prospective solutions and may be reasonable agrotechnical options for sustainable agriculture. This research was undertaken because of the potentially high productivity of the afila morphotype in good wheat complex soils. Its cultivation should be developed in such conditions, thus obtaining the best economic efficiency. The objective of the research was to assess the productivity, seed yield and vegetation indices of the pea canopy after seed vaccination with Rhizobium and foliar micronutrient fertilization.

\section{MATERIALS AND METHODS}

The research was based on a controlled field experiment, conducted in four replications and carried out in the experimental field of the Bayer company located in Modzurów (5009'N 1807'E), Silesian voivodeship. The experimental field soil was Umbrisol - slightly degraded chernozem, formed from loess, classified as good wheat complex and soil class II, therefore the soil conditions were sufficient for the needs of pea (Pisum sativum $\mathrm{L}$.). The soil $\mathrm{pH}$ was neutral ( $\mathrm{pH}$ in $1 \mathrm{~mol} \times \mathrm{dm}^{-3}$ $\mathrm{KCl}-6.28$ ) and the nutrient-richness of the topsoil layer was high: phosphorus $19.1 \mathrm{mg} \times 100 \mathrm{~g}^{-1}$ soil; potassium $21.7 \mathrm{mg} \times 100 \mathrm{~g}^{-1}$, and magnesium $10.1 \mathrm{mg} \times 100 \mathrm{~g}^{-1}$ soil. A randomized design was used in the present field experiment and it consisted of 4 replications, while the size of each plot was $8.4 \mathrm{~m}^{2}$. The following pre-sowing doses were applied: phosphorus $-5.1 \mathrm{~kg} \mathrm{P} \times \mathrm{ha}^{-1}$ and potassium $-14.4 \mathrm{~kg} \times \mathrm{K} \mathrm{ha}^{-1}$. Ammonium nitrate was applied as the "starting dose" $-20 \mathrm{~kg} \mathrm{~N} \times$ ha $^{-1}$. Seeds were sown at a depth of $6 \mathrm{~cm}$, with row spacing of $15 \mathrm{~cm}$. Sowing density was 120 seeds $\times \mathrm{m}^{-2}$ for the afila cultivar 'Tarchalska' of pea. A commercial vaccine, Nitragina $^{\mathrm{TM}}$ inoculant produced by the company BIOFOOD (Poland), was applied immediately before sowing according to the recommendations of the manufacturer, the company BIOFOOD, and the applicable methodology (D e a k e r et al. 2004). April of 2009 was a very dry month $(6.1 \mathrm{~mm}$ precipitation) and this reduced the density of pea plants because germination was poor. On the other hand, a two-week period of rainfall occurred after sowing (59.5 mm precipitation) in 2010 , which also resulted in poor germination. The foliar fertilizer Photrel $^{\mathrm{TM}}$ was applied at a rate of $3 \mathrm{dm}^{3} \times \mathrm{ha}^{-1}$ at the beginning of pea budding. Photrel is a foliar fertilizer containing 5\% B, $7 \% \mathrm{Mn}, 0.4 \% \mathrm{Mo}, 13.3 \% \mathrm{MgO}$, and $36.3 \% \mathrm{SO}_{3}$. By using this foliar micronutrient fertilizer, the following amounts of nutrients were applied on a per hectare basis: $150 \mathrm{~g} \mathrm{~B}, 210 \mathrm{~g} \mathrm{Mn}, 12 \mathrm{~g} \mathrm{Mo}, 400 \mathrm{~g}$ $\mathrm{MgO}$, and $1081 \mathrm{~g} \mathrm{SO}_{3}$. At the end of the flowering stage, the presence of the pea weevil (Bruchus pisorum) and pea moth (Laspeyresia nigricana) was controlled with Nurelle D 550 EC at a rate of $0.51 \mathrm{ha}^{-1}$.

Green area index of the canopy $\left(\mathrm{m}^{2} \times \mathrm{m}^{-2}\right)$, photosynthetically active radiation and normalized difference vegetation index (NDVI) were determined at characteristic growth stages. Before harvest - during the ripening stage -15 pea plants were sampled from the plots in order to perform biometric analysis. Total plant length, including the height to the first pod, length of the fruiting part of the shoot, number of nodes, and number of pods growing from the consecutive nodes were determined. Plants were harvested with a plot harvester. After collection, seeds were cleaned and the moisture content was determined. The final seed yield per plot was calculated for the water content of $14.5 \%$. The obtained results were analysed by analysis of variance with the use of Statistica 9.1 software.

\section{RESULTS}

At the advanced growth stages - from budding to the flat pod stage - a relatively high green area index (GAI) (Table 1) was observed for the pea crop analyzed. Apart from the photosynthetic surface area of the canopy, high photosynthetically active radiation (PAR) values were obtained. The use of vaccination with Rhizobium resulted in higher GAI and PAR values, but the differences between the treatments remained statistically insignificant. At the flat pod stage, the value of GAI reached 4.90. The value of this index was the highest (5.19) in 2010 and the lowest (3.75) in 2009. The highest GAI values at the budding-flowering stages were obtained in the treatment with the 
inoculant, while at the flat pod stage these values were the highest after additional application of Photrel. The application of seed inoculation with Rhizobium and the microelement fertilizer did not affect the GAI values, but it did not also increase the photosynthetic activity of plants (PAR and NDVI).

Despite a considerable variation in total precipitation in 2009-2010, the differences in total pea seed yield in the present study were only $10 \%$ - from 32.2 $\mathrm{dt} \times \mathrm{ha}^{-1}$ in 2009 to $36.7 \mathrm{dt} \mathrm{ha}^{-1}$ in the most rainy year -2010 (Fig. 1). The seed yield was higher in the treatments with the inoculant Nitragina (35.8 dt $\left.\times \mathrm{ha}^{-1}\right)$, however in the other treatments this value was similar $\left(32.8-35.4 \mathrm{dt} \times \mathrm{ha}^{-1}\right)$. In our study, an excessive amount of water decreased plant productivity and the number of internodes, while it did not have any significant impact on the GAI value (Table 1).

During the subsequent stages of plant growth, the NDVI value decreased as a result of the development of stems and generative organs (Table 1). A significant differentiation of GAI at the ripening stage of pea was found only in the worse year in terms weather conditions. The NDVI value was also significantly lower in 2010, which resulted from longer periods of rainfall during the growing season, and this caused a decrease in chlorophyll content in plants (Table 1). The NDVI value did not vary between treatments at the successive growth stages. The highest value of NDVI was observed at the budding stage, while a decrease in leaf chlorophyll content was observed at the subsequent stages. On the other hand, a significant differentiation was observed between the years of the study. At the flowering stage, the NDVI value reached 0.75 , while at the flat pod stage in 2010 it reached 0.59. The analysis of the morphological traits of pea at full ripeness (harvest of plants) revealed that both the separate application of inoculant 'Nitragina' and combined application with Photrel reduces the height to the first fruiting internode. In comparison to the other treatments, pods formed significantly lower on the shoot, counting from the ground level (Table 2). The separate application of Photrel or its combined application with Nitragina increased the fruiting part of the shoot, which caused a significant increase in the percentage proportion of the shoot with pods in total shoot length.

The application of inoculation with Rhizobium decreased not only the total shoot length, which was mentioned earlier, but also decreased the length of a single internode. This impact was particularly visible in the combined use of Nitragina with Photrel (Table 3). The combined use of Nitragina and Photrel increased the number of pods per pea shoot, but it also affected the number of pods formed within a single internode. Such results indicate the possibility of controlling the growth of afila morphotypes of pea (to some extent) and of improving the productivity of a shoot through a definite and significant increase in the number of pods.

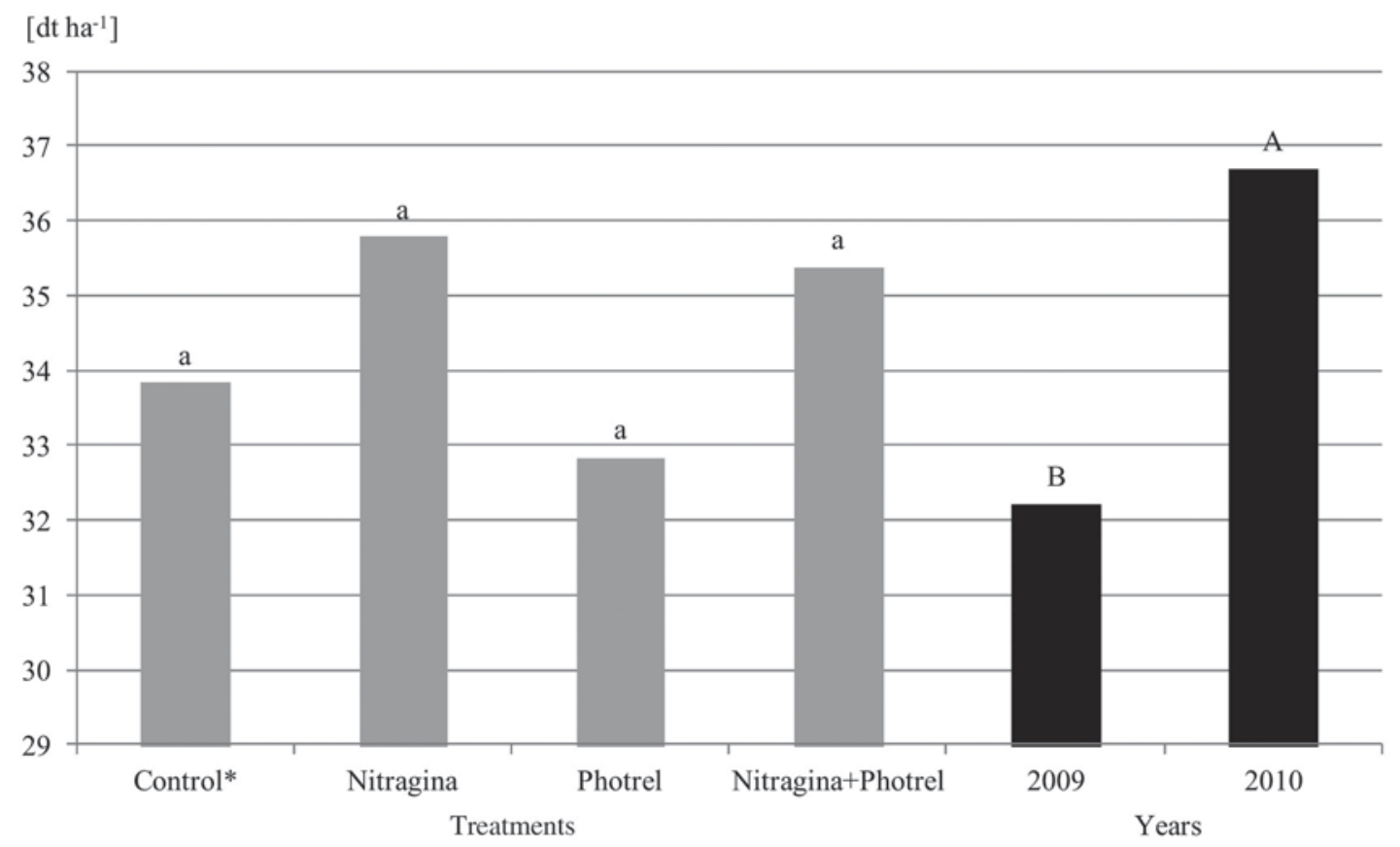

* Control - uninoculated and without foliar fertilization

Means marked with the same letter do not differ statistically

Fig. 1. Seed yield of pea depending on Rhizobium inoculation - Nitragina and foliar application of the microelement fertilizer Photrel during the two years of the experiment. Means marked with different letters are significantly different; bars designated with different letters are significantly different at the level of $\mathrm{p}=0.05$. 
Table 1

Changes in the leaf area index $\left(\mathrm{m}^{2} \mathrm{~m}^{-2}\right)$, photosynthetically active radiation (PAR), and normalized difference vegetation index (NDVI) at the characteristic growth stages of pea

\begin{tabular}{|c|c|c|c|c|c|c|c|c|c|}
\hline \multirow{3}{*}{ Treatments } & \multicolumn{9}{|c|}{ Growth stages } \\
\hline & \multicolumn{3}{|c|}{ Budding } & \multicolumn{3}{|c|}{ Flowering } & \multicolumn{3}{|c|}{ Flat pod } \\
\hline & GAI & PAR & NDVI & GAI & PAR & NDVI & GAI & PAR & NDVI \\
\hline Control* & 3.19 & 90.08 & 0.70 & 3.38 & 95.70 & 0.62 & 4.28 & 95.37 & 0.61 \\
\hline Nitragina & 3.46 & 92.13 & 0.70 & 3.64 & 96.86 & 0.65 & 4.85 & 96.40 & 0.62 \\
\hline Photrel & 2.94 & 87.72 & 0.70 & 3.54 & 96.44 & 0.63 & 4.80 & 97.05 & 0.61 \\
\hline Nitragina + Photrel & 2.71 & 87.19 & 0.70 & 3.55 & 96.48 & 0.62 & 4.90 & 97.24 & 0.61 \\
\hline $\mathrm{LSD}_{0.05}$ & NS & NS & NS & NS & NS & NS & NS & NS & NS \\
\hline \multicolumn{10}{|l|}{ Years } \\
\hline 2009 & 3.08 & 89.28 & 0.70 & 3.48 & 98.03 & 0.75 & 3.75 & 92.80 & 0.65 \\
\hline 2010 & - & - & - & 3.55 & 95.54 & 0.57 & 5.19 & 98.37 & 0.59 \\
\hline $\operatorname{LSD}_{0.05}$ & - & - & - & NS & 1.032 & 0.042 & 0.510 & 1.408 & 0.021 \\
\hline
\end{tabular}

Control* - uninoculated and without foliar fertilization; NS - not significant

Table 2

Characteristics of total pea shoot length $(\mathrm{cm})$, including the height to the first pod, and the percentage (\%) of the part with pods in total shoot length

\begin{tabular}{|c|c|c|c|c|}
\hline Treatments & $\begin{array}{l}\text { Height of the first pod in } \\
\text { the shoot }[\mathrm{cm}]\end{array}$ & $\begin{array}{l}\text { Length of the shoot } \\
\text { with pods [cm] }\end{array}$ & $\begin{array}{l}\text { Total shoot lengthPerce } \\
{[\mathrm{cm}]}\end{array}$ & $\begin{array}{l}\text { centage of the part with pods } \\
\text { in total shoot length [\%] }\end{array}$ \\
\hline Control* & $65.8 \pm 12.6 * *$ & $24.8 \pm 12.0$ & $90.6 \pm 16.8$ & $26.8 \pm 10.0$ \\
\hline Nitragina & $60.6 \pm 12.7$ & $24.1 \pm 12.1$ & $84.7 \pm 17.0$ & $27.8 \pm 10.6$ \\
\hline Photrel & $63.3 \pm 11.5$ & $30.1 \pm 12.5$ & $93.4 \pm 15.4$ & $31.6 \pm 10.5$ \\
\hline Nitragina + Photrel & $59.9 \pm 10.5$ & $30.2 \pm 11.2$ & $90.1 \pm 13.3$ & $33.1 \pm 10.1$ \\
\hline $\mathrm{LSD}_{0.05}$ & 4.83 & 5.65 & 6.13 & 5.05 \\
\hline \multicolumn{5}{|l|}{ Years } \\
\hline 2009 & $65.5 \pm 13.7$ & $31.7 \pm 13.4$ & $97.2 \pm 14.7$ & $32.2 \pm 12.2$ \\
\hline 2010 & $59.3 \pm 9.0$ & $22.9 \pm 9.1$ & $82.2 \pm 13.3$ & $27.4 \pm 8.0$ \\
\hline $\mathrm{LSD}_{0.05}$ & 2.59 & 3.03 & 3.29 & 2.71 \\
\hline
\end{tabular}

*Control - uninoculated and without foliar fertilization

**mean $( \pm \mathrm{SD})$

Table 3

Comparison of a single internode length $(\mathrm{cm})$ within the pea shoot, number of fruiting internodes and pods, including the number of pods formed within the fruiting internode

\begin{tabular}{lcccc}
\hline \multirow{2}{*}{ Treatments } & $\begin{array}{c}\text { Internode length } \\
{[\mathrm{cm}]}\end{array}$ & Internode & Numbers $\left[\mathrm{n}_{\mathrm{o}}\right]$ \\
\cline { 3 - 5 } & $5.8 \pm 1.8^{* *}$ & $4.27 \pm 1.73$ & Pod & Pods per internode \\
\hline Control* & $5.7 \pm 2.1$ & $4.32 \pm 1.81$ & $6.63 \pm 2.54$ & $1.59 \pm 0.26$ \\
Nitragina & $7.1 \pm 2.9$ & $4.58 \pm 2.11$ & $6.48 \pm 2.62$ & $1.51 \pm 0.31$ \\
Photrel & $5.9 \pm 1.5$ & $5.20 \pm 1.92$ & $6.93 \pm 3.52$ & $1.49 \pm 0.28$ \\
Nitragina + Photrel & 0.98 & 0.795 & $8.45 \pm 3.16$ & $1.63 \pm 0.24$ \\
LSD & & & 1.358 & 0.125 \\
Years & $6.0 \pm 2.2$ & $5.48 \pm 2.12$ & $8.10 \pm 3.43$ & $1.47 \pm 0.28$ \\
2009 & $6.3 \pm 2.2$ & $3.70 \pm 1.15$ & $6.15 \pm 2.29$ & $1.64 \pm 0.25$ \\
2010 & $\mathrm{NS}$ & 0.426 & 0.728 & 0.067 \\
LSD $_{0.05}$ & & & & \\
\hline
\end{tabular}

*Control - uninoculated and without foliar fertilization

$* *$ mean $( \pm \mathrm{SD})$ 


\section{DISCUSSION}

The use of inoculation as the source of effective Rhizobium bacteria for pea resulted in higher GAI and PAR values. The highest values of GAI at the budding-flowering stages were obtained in the treatment with Nitragina, while at the flat pod stage these values were the highest after additional application of Photrel. The application of Nitragina inoculation and microelement fertilizer did not affect the GAI values, but it did not also increase the photosynthetic activity of plants (PAR and NDVI), which was denied by $\mathrm{N} g$ e $\mathrm{n}$ o et al. (2012). N a l b o r c z y k (1993) indicated that the afila morphotypes compensate smaller photosynthetic area of leaves by improving the light relations inside the canopy and by obtaining better canopy aeration. These factors probably determined the effectiveness of foliar microelement application.

The differences in total pea seed yield in the present study were only $10 \%$ - from $32.2 \mathrm{dt} \times \mathrm{ha}^{-1}$ to $36.7 \mathrm{dt} \mathrm{ha}^{-1}$. The seed yield was higher in the treatments with Nitragina, but in the other treatments this value was similar $-35 \mathrm{dt} \times \mathrm{ha}^{-1}$. Other authors (M e r te n s et al. 2011, Andrzejewska, 2002, Z a ją c et al. 2013) have also indicated the fact that the response of pea varieties to Nitragina application and microelements differs between years. As presented by $\mathrm{Z} \mathrm{a} \mathrm{j} \mathrm{ą} \mathrm{c}$ et al. (2012), both the growing period and pod yield are strongly correlated with weather conditions and - to a lower extent - with cultivation technology ( $\mathrm{K}$ s i ę $\dot{z}$ ak et al. 1998; Helios and Kotecki, 2006). In the the present study, excess water decreased the number of pods produced and the number of internodes, while it did not have any significant impact on the LAI value. The divergent results of the observations in controlled conditions were obtained by $\mathrm{W}$ e s t $\mathrm{g}$ a te (1999) who found that the maximum efficiency of photosynthesis and the maximum seed yield are strongly correlated with the photosynthesis (GAI). This issue was studied by Lepiarczyk et al. (2005) and Prusiński (2007) using extensive cultivation - without mineral fertilizers and with reduced tillage - and they found that any departure from agrotechnical practices significantly reduced the GAI value. This was also confirmed in the research carried out by Szwejkowska (2004) which showed that the level of expenditure on pea cultivation using comparable agricultural technologies significantly affected pea seed yield and partly compensated for adverse weather conditions during the growing seasons, irrespective of cultivar.

In the following plant development stages, the NDVI value did not vary between treatments at the successive growth stages. The maximum NDVI value was observed at the budding stage, while the minimum chlorophyll content in leaves was observed at the subsequent stages. At the flowering stage the NDVI value reached 0.75 , while at the flat pod stage in 2010 it reached 0.59. Examining the NDVI values in chickpea, L a f ond (2002) demonstrated that the content of chlorophyll in leaves was significantly higher after nitrogen application. The NDVI value increased linearly at the flowering stage, regardless of nitrogen rate. $\mathrm{G}$ a $\mathrm{n}$ et al. (2003) showed that an additional $\mathrm{N}$ dose of $15 \mathrm{~kg} \times \mathrm{ha}^{-1}$ at the ripening stage of lentil influenced the reduction of the root nodules, but it did not affect the yield.

The analysis of the morphological traits of pea revealed that both separate application of inoculation with Rhizobium and combined application with Photrel reduce the height of the first fruiting internode. Separate application of Photrel or combined application with Nitragina increased the fruiting part of the shoot, which caused a significant increase in the percentage proportion of the shoot with pods in total shoot length. These results correspond with the research by Roponen and Virtanen (2006) who observed that inoculated plants are more luxuriant, bloom a few days later and ripen a little later. The present study showed that atmospheric conditions were also important. The studies by K o te c ki (1990), C z y ż (1993) and Andrzejewska (2002) reported that the increase of seed yield affected by microelement fertilization resulted from the increase in the number of pods per plant and - to a lower extent - from the increase in the number of seeds per pod. P y t larz-Kozi cka (2010) obtained different results in her study of lupine; the author showed that inoculation with Nitragina had a significant effect on increasing seed yield. However, the author of this study did not obtain any significant variation in the height of the first pod, number of pods per plant or number of seeds per pod. The increase in the number of pods formed in the fruiting internode in the present study was significantly affected by precipitation. Adverse rainfall conditions in 2010 did not compensate the loss of pods in the fruiting internode.

Application of Nitragina decreased not only the total shoot length, which was mentioned earlier, but also decreased the length of a single internode. This effect was particularly visible in the combined application of inoculation with nodule bacteria using Nitragina and Photrel. The combined use of Nitragina and Photrel increased the number of pods per pea shoot, but it also affected the number of pods formed within a single internode. Such results indicate the possibility of controlling the growth of afila morphotypes of pea (to some extent) and of improving the productivity of a shoot through a definite and significant increase in the number of pods. Analyzing the influence of nodulation on the morphological traits of various bean varieties, Y a d a v (1996) demonstrated a significant 
impact of this process on the number and size of nodules. However, the author did not obtain any significant differentiation of plant size after inoculation. The same author obtained a significant variation in the yield components of the analyzed bean genotypes. A significant increase in the number of pods, number of seeds per pod and seed weight was observed after Nitragina application. Different results were obtained in the present study - a significant differentiation in the morphological traits of pea, depending on the treatment, was obtained after Nitragina application. Significantly lower pea shoots were observed after Nitragina application. Additional foliar application of Photrel (Nitragina + Photrel) resulted in a significantly higher number of pods per shoot, which resulted in a higher number of fruiting internodes, higher number of pods in the internode and number of pods. Studies on the effectiveness of Rhizobium inoculation have concentrated on investigating the factors supporting the activity and effectiveness of the symbiosis with plants. Microelement fertilization may be one of these factors. The issue of microelements in pea cultivation was comprehensively evaluated by Czy ż (1993), B ochniarz et al. (1987), N ow ot ny - Mieczyńska and Araźna (1965) as well as Vanek and Knop (1972) who investigated the relationship between microelement application and nodulation. The results of most studies indicated increased nodulation under the influence of foliar application of molybdenum. The study of A n drzeje w ska (2002) showed a significant relationship between an increase in yield and foliar application of microelement fertilizers, but soil inoculation did not affect the structural components of the pea yield. Moreover, Andrzejewska (2002) did not show the interaction of Nitragina and microelement application regarding pea yield. The increase in seed yield in the present research, similarly to the studies by the former author, resulted from the increase in the number of internodes and pods in the fruiting part of the shoot.

\section{CONCLUSIONS}

The presented results of this study on symbiotic nitrogen fixation by leguminous plants show that the combined application - foliar application of micronutrient fertilizer and seed inoculation with Nitragina seems appropriate. It is not recommended to use foliar fertilizers or Nitragina separately due to the slowing of pea growth. The activity of $\mathrm{N}_{2}$ fixation by legumes, expressed by the GAI, PAR and NDVI values, mostly depended on humidity conditions and temperature. The application of inoculation with Nitragina and the foliar fertilizer Photrel resulted in changes in the morphological traits of pea - the lower formation of pods and elongation of the fruiting part of the shoot as well as an increase of the percentage proportion of the fruiting part of the shoot in total shoot length. Productivity was determined by the number of pods per shoot. The negative impact of weather conditions in 2010 resulted in a significant decrease in the number of internodes per shoot and number of pods per shoot. The selected physiological indicators showed the formation of the optimum leaf area which effectively used photosynthetically active radiation. The use of inoculation with Rhizobium for pea plants resulted in slightly higher GAI values and the optimization of PAR and NDVI use.

\section{Acknowledgements}

The study was carried out within the research project N N310 151837.

\section{Author's contributions}

The The following declartions about authors' contributions to the research have been made: designing the experiment: TZ, AK-K, AO; field reserach: TZ, AK-K, AO; data analysis; TZ, AK-K, AO; comments on the manuscript: TZ, AK-K, AO, AO; writting the manuscript; TZ, AK-K, AO.

\section{REFERENCES}

Andrzejewska J. 2002. Yield and agronomic conditions of nodulation in different pea varieties (Pisum sativum L.). Rozp. Hab., 105. Bydgoszcz. pp. 91. (in Polish). oai:kpbc.umk.pl:53728 http://kpbc.umk.pl/publication/44210

Annicchiarico P., Iannucci A. 2008. Adaptation strategy, germplasm type and adaptive traits for field pea improvement in Italy based on variety response across climatically contrasting environments. Field Crop Res., 108: 133-142. http://dx.doi.org/10.1016/j. fcr.2008.04.004

Armstrong E.L., Pate J.S., Tennant D. 1994. The field pea crop in south western Australia-patterns of water use and root growth in genotypes of contrasting morphology and growth habit. Aust. J. Plant Physiol., 21:517-532. http://dx.doi.org/10.1071/PP9940517

Baigorri H., Antolin M.C., Sanchez-Diaz M. 1999. Reproductive response of two morphologically different pea cultivars to drought. Eur. J. Agron., 10: 119-128. http://dx.doi.org/10.1016/S1161-0301(99)00 $002-7$

Bochniarz J., Bochniarz M., Lenartowicz W. 1987. Effect of seed inoculation and molybdenum and nitrogen fertilization on the yield of faba bean (Vicia faba minor). Pam. Puł., 89: 1-40. (in Polish).

Boros L., Sawicki J. 1997. Evaluation of selected pea (Pisum sativum L.) cultivars and forms. II. Stability of yielding parameters and trait interrelationships. Zesz. Probl. Post. Nauk Rol., 446: 107-112. (in Polish). 
Carranca C., de Varennes A., Rolston D. 1999. Biological nitrogen fixation by fixation by fababean, pea and chickpea, under field conditions, estimated by the ${ }^{15} \mathrm{~N}$ isotope dilution technique. Eur. J. Agron. 10: 49-56. University of California, Davis, California, USA. http:// dx.doi.org/10.1016/S1161-0301(98)00049-5

Corre-Hellou G., Crozat Y. 2005. $\mathrm{N}_{2}$ fixation and $\mathrm{N}$ supply in organic pea (Pisum sativum L.) cropping systems as affected by weeds and peaweevil (Sitona lineatus L.). Eur. J. Agron. 22: 449-458. http://dx.doi. org/10.1016/j.eja.2004.05.005

Czy ż H. 1993. Reaction of pea varieties to foliar fertilization of boron, manganese and molybdenum. Frag. Agron., 1(37): 139-160. (in Polish).

Deaker R., Roughley R.J., Kennedy I.R.2004.Legume seed inoculation technology - a review. Soil Biol. \& Biochem., 36:1275-1288. http://dx.doi.org/10.1016/ j.soilbio.2004.04.009

Dun E. Ferguson B., Beveridge C. 2006. Apical dominance and shoot branching. Divergent opinions or divergent mechanisms? Plant Physiol., 142: 812-819. http://dx.doi.org/10.1104/pp.106.086868

Gronowicz Z., Fordoński G., Klicka I. 1989. Effect of Florovit fertilization and row spacing on the yield of new varieties of pea. Conference; Natural and agronomic conditions for the production of legumes. Part II. IUNG. Puławy, 116-122. (in Polish).

Helios W., Kotecki A. 2006. Effect of N fertilization and the harvest date on the accumulation of dry weight, organic and mineral nutrients in plant of selected pea cultivars. EJPAU, 9(4). http://www.ejpau.media.pl/volume9/issue4/art-14.html

Jensen E.S. 1996. Nitrogen acquisition by pea and barley and effect of their crop residues on available nitrogen for subsequent crops. Biol. Fertil. Soils, 23: 459-464. http://dx.doi.org/10.1007/BF00335923

Je uffroy M-H., Ney B . 1997. Crop physiology and productivity. Field Crop Res., 53: 3-16. http://dx.doi.org/ 10.1016/S0378-4290(97)00019-1

Jeuffroy M-H., Sebillote M. 1997. The end of flowering in pea: influence of plant nitrogen nutrition. Eur. J. Agron., 6: 15-24. http://dx.doi.org/10.1016/S1161-03 01(96)02028-X

Klimek A., Zając T. 2009. Pea (Pisum sativum L.) productivity against the background of breeding progress. Post. Nauk Rol., 1: 77-91. (in Polish).

Kotecki A. 1990. Effect of molybdenum foliar fertilization on yield of pea varieties. Zesz. Nauk. AR we Wrocławiu, Rol. LII: 121-132. (in Polish).

Księżak J., Lenartowicz W., Ufnowska J. 1998. Economic efficiency of selected production technologies of pea seeds. Rocz AR Poznań CCCVII: part II, 5-11. (in Polish).

Kulig B., Ziółek W. 1996. Diversity of yielding in different pea and faba bean varieties depending on nitrogen fertilization. Zesz. Prob. Post. Nauk Rol. 446: 207-212. (in Polish).
Lafond, G., and Johnston A. 2002. Field pea yieldeffect of inoculant formulation and nitrogen fertilizer. Agri-Food Innovation Fund research report 2002. Saskatchewan, Canada.

Lepiarczyk A., Kulig B., Stępnik K. 2005. Effect of reduced tillage on yield and the leaf area index of spring barley and faba bean. Bibl. Fragm. Agron. 9: 101-102. (in Polish).

Martyniak J. 1997. Biological progress in leguminous crops during economic transformation in Poland. Zesz. Probl. Post. Nauk Rol., 446: 33-41. (in Polish).

Mertens C., Dehon L., Bourgeois A., Verhaeghe-Cartrysse C., Blecker C. 2011. Agronomical factors influencing the legumin/vicilin ratio in pea (Pisum sativum L.) seeds. J. Sci. Food Agric. 92: 1591-1596. http://dx.doi.org/10.1002/jsfa.4738

Nalborczyk E. 1993. Biological determinants of legume productivity. Frag. Agron., 4: 147-150. (in Polish).

Ngeno J., George N., Muthomi James W., Shibairo Solomin I. 2012. Effect of Rhizobium inoculation and nitrogen fertilizer application on growth, nodulation and yield of two garden pea genotypes.Jour. Anim.\& Plant Sci. 15(2): 2147-2156. http://www. m.elewa.org/JAPS; ISSN 2071-7024, http://dx.doi.org/ 10.5897/AJB09.1039

Poggio S.L., Satorre E.H., Dethiou S., Gonzallo G.M. 2005. Pod and seed numbers as a function of photothermal quotient during the seed set period of field pea (Pisum sativum) crop. Eur. J. Agron. 22: 55-69. http://dx.doi.org/10.1016/j.eja.2003.12.003

Prusiński J. 2007. Selected indicators of pea productivity under increasing intensity of cultivation technology. Acta Sci. Pol., Agric. 6(4): 43-51. (in Polish).

Pytlarz-Kozicka M. 2010. Effect of plant protection and nitagine vaccination on health and yield of two varieties of yellow lupine. Prog. Plant Prot. 50(1): 47-51. (in Polish).

Roponen I., Virtanen A. 2006. The effect of prevention of flowering on the vegetative growth of inoculated pea plants. Physol. Plant., 21(3): 655-667. http://dx.doi. org/10.1111/j.1399-3054.1968.tb07290.x

S m il V. 1997. Some unorthodox perspectives on agricultural biodiversity. The case of legume cultivation. Agric. Ecosyst.\& Environ. 62: 135-144. http://dx.doi.org/ 10.1016/S0167-8809(96)01138-3

Szwejkowska B. 2004. Effect of tillage method on pea yield. Frag. Agron. 3(83): 120-126. (in Polish).

Vanek P., Knop K. 1972. Vliv molibdenu a kobaltu na fixaci dusiku u hrachu. Rostl. Vyroba, 18(5): 521-529. (in Czech).

Westgate M.E. 1999. Managing soybeans for photosynthetic efficiency. In Crop, Soil and Water Managemnet. Proc. World Soybean Research Conference VI. 223-228.

Yadow A.S., Rai S., Upadliyay K.K.S., Sawhney S.K., Vashishat R.K. 1996. Nitrogen fixing efficiency and rate of respiration of azide sensitive and resistant strains of Bradyrhizobium sp. (Vigna). 
In:Kahlon, R.S.(Ed.), Perspectives in Microbiology 1996, National Agricultural Technology Information Centre.India: Ludhiana. 171-174. http://www.scielo.br/ scielo. en

Zając T., Klimek-Kopyra A., Oleksy A., Lenart A. 2013. Vertical distribution of Pea (Pisum sativum L.) seed yield depending on the applied bacterial inoculants. J. Agric. Sci. 5(1): 260-268. http://dx.doi. org/10.5539/jas.v5n1p260

Zając T., Oleksy A., Stokłosa A., KlimekKopyra A., Kulig A. 2013. The development competition and productivity of linseed and pea-cultivars grown in a pure sowing or in a mixture. Eur. J. Agr. 44: 22-31. http://dx.doi.org/10.1016/j.eja.2012. 08.001

\section{Wpływ szczepienia Rhizobium oraz dolistnego nawożenia na potencjał produkcyjny grochu siewnego (Pisum sativum L.)}

\section{Streszczenie}

Spośród roślin strączkowych groch siewny uznawany jest za drugą istotną roślinę świata, o szerokim zakresie wykorzystania zarówno na cele jadalne jak i paszowe. Głównym czynnikiem determinującym wykorzystanie grochu jest potencjał plonowania odmian. Obecnie uważa się, że przedsiewne szczepienie nasion grochu i dolistne dokarmianie roślin nawozem mikroelementowym to rozwiązania perspektywiczne dla rolnictwa. Podjęcie badań wynika z potencjalnie dużego znaczenia morfotypu wąsolistnego $\mathrm{w}$ warunkach gleb dobrych (pszennych), którego uprawę w tych warunkach siedliska należy rozwijać, uzyskując przy niej jak najlepszą efektywność ekonomiczną. Celem badań było określenie wpływu szczepienia bakteriami Rizobium i nawożenia dolistnego mikroelementami na plonowanie wąsolistnej odmiany grochu siewnego 'Tarchalska'. Ścisłe doświadczenie polowe prowadzono w latach 2009-2010, na polu doświadczalnym firmy Bayer® zlokalizowanym w miejscowości Modzurów, woj. śląskie.

Doświadczenie polowe prowadzono na czarnoziemie słabo zdegradowanym, wytworzonym z lessu, zaliczanym do kompleksu pszennego dobrego i II-giej klasy bonitacyjnej. Bezpośrednio przed siewem nasiona grochu zaszczepiono bakteriami Rizobium (Nitragina).

Oznaczano w charakterystycznych fazach rozwojowych grochu indeks zielonej powierzchni liści łanu (GAI), fotosyntetycznie czynną radiację (PAR) i różnicowy znormalizowany indeks wegetacji (NDVI). Łączna aplikacja szczepionki bakteryjnej Nitragina i nawozu dolistnego Photrel była najlepszą kombinacją dla produkcyjności. Zdalne pomiary wskaźników łanu grochu wskazały wykształcenie optymalnej zielonej powierzchni asymilacyjnej, która sprawnie wykorzystywała fotosyntetycznie czynną radiację. Zastosowanie nitraginy jako donora efektywnych Rhizobium dla grochu sprawiło, że w tych obiektach uzyskano większy GAI i konsekwentnie PAR, ale różnice międzyobiektowe pozostały statystycznie nieistotne. 